\title{
Effect of Drip Irrigation Levels on Yield of Salad Cucumber under Naturally Ventilated Polyhouse
}

\author{
V.M. Abdul Hakkim ${ }^{1}$, A.R. Jisha Chand ${ }^{2}$ \\ ${ }^{1}$ Principal Investigator, ${ }^{2}$ Research Associate Precision Farming Development Centre (PFDC), Kerala \\ Agricultural University, KCAET, Tavanur (P.O.), Malappuram (Dist), Kerala - 679 573, India.
}

\begin{abstract}
An experiment was conducted to study the yield response of salad cucumber under different drip irrigation levels to determine the most suitable irrigation requirement for salad cucumber grown under naturally ventilated polyhouse. Drip irrigation applied at the rate of 2 litre plant $^{-1}$ day ${ }^{-1}$ to the control plants was reduced by $5,20,35$ and $50 \%$ by applying corresponding irrigation rates of $1.9,1.6,1.3$ and 1 litre plant ${ }^{-1}$ day $^{-1}$ under different treatments. Lowering irrigation level to $65 \%$ sustained the production and increased water use efficiency without decreasing the yield of cucumber. However, irrigation level of less than $65 \%$ reduced the yield without increasing water use efficiency. The maximum fruit number (49), fruit weight (7.194 kg plant $\left.{ }^{-1}\right)$ and fruit yield $\left(88.8 \mathrm{t} \mathrm{ha}^{-1}\right)$ were obtained from drip irrigation level of $65 \%\left(1.3\right.$ litre plant ${ }^{-1}$ day $\left.^{-1}\right)$ and the lowest fruit number (35), fruit weight $\left(5.043 \mathrm{~kg} \mathrm{plant}^{-1}\right)$ and fruit yield $\left(62.26 \mathrm{t} \mathrm{ha}^{-1}\right)$ from drip irrigation level of $50 \%$ (1 litre plant ${ }^{-1}$ day $\left.^{-1}\right)$, with the lowest water application rate . Irrigation treatments had significant effects ( $\mathrm{P}$ $<0.05)$ on yield. However, interaction within groups was found to be non significant. There were significant positive correlations $(\mathrm{P}<0.01)$ between fruit number, fruit weight and fruit yield. The total quantity of water applied through $65 \%$ drip irrigation level was $144.4 \mathrm{~mm}$ and which showed 35 per cent water saving over control with highest water use efficiency $\left(6148.31 \mathrm{~kg} \mathrm{ha}^{-1} \mathrm{~cm}^{-1}\right)$ and Benefit Cost (BC) ratio (3.41).
\end{abstract}

Keywords: - Cucumis sativus, Drip irrigation, Economics, Naturally ventilated polyhouse, Water use efficiency

\section{INTRODUCTION}

Efficient use of available irrigation water is essential for increasing agricultural production for the alarming Indian population. Water availability for irrigation is going to be a major constraint for agriculture in the near future. Hence, judicious use of the available water resources through more efficient methods of water application like drip irrigation under conditions of protected cultivation becomes necessary to enhance the yield and water use efficiency (Dunage et al., 2009). Protected cultivation of vegetables provides the best way to increase the productivity and quality of vegetables, especially cucurbits. Naturally ventilated greenhouses are highly suitable for year round cultivation of parthenocarpic cucumber varities. High frequency water management by drip irrigation provides daily requirement of water to a portion of the root zone of each plant and maintains a high soil matric potential in the rhizosphere to reduce plant water stress (Nakayama and Bucks, 1986).

The cucumber (Cucumis sativus L.) is an important and big group of vegetables belonging to the family cucurbitaceae. Cucumber has tremendous economic and dietic importance. The immature fruits are eaten raw as salad. Cucumber is a coarse prostrate, annual vining plant with stiff hairs or spines on leaves and stems. Unbranched lateral tendrils developed at the leaf axils. As the lateral branches are developed, flower clusters appear at leaf axils (Maqsood et al., 2004).

Many studies were reported on cucumber cultivation under protected conditions. Wang et al. (1999) studied the relationship between irrigation amount, yield and quality of cucumber under greenhouse. Xiaobo et al. (2002) studied the water requirement of cucumber for different cropping in solar greenhouse. Reducing water supply at seedling stage, controlling water supply at flowering stage and increasing water supply at fruiting stage of cucumber can increase yield and water use efficiency (Shao et al., 2010). Keeping in view the above facts, the present study was undertaken to determine the most suitable irrigation requirement for salad cucumber grown under naturally ventilated polyhouse.

\section{MATERIAL AND METHODS}

The experiment was conducted inside the Naturally Ventilated Polyhouse (NVPH) of $292 \mathrm{~m}^{2}$ area located at Precision Farming Development Centre, KCAET, Tavanur during May- August 2013. The study area is located between $10^{\circ} 52^{\prime} 30^{\prime \prime}$ North Latitude and $75^{\circ} 58^{\prime} 34^{\prime \prime}$ East Longitude and oriented in the east west direction. The soil of the experimental site was well drained laterite soil. The experimental setup consisted of screen filter, main, sub mains, laterals, drippers and other accessories required for drip irrigation. A 5 HP submersible pump was used to lift water from the bore well and supply to the drip irrigated plot. The main and sub main pipelines used for drip irrigation were made of PVC pipes of $63 \mathrm{~mm}$ and $50 \mathrm{~mm}$ diameter respectively. 
Linear Low Density Poly Ethylene (LLDPE) pipes of $16 \mathrm{~mm}$ diameter were used for laterals in the drip irrigation treatments. Drippers of 4 litres per hour (lph) capacity were fitted on the laterals at a spacing of $90 \mathrm{~cm}$.

The experiment was laid out under completely randomized design with salad cucumber hybrid Hilton F1 as the test crop. Spacing adopted for single row planting was $90 \mathrm{~cm}$ x $90 \mathrm{~cm}$ on raised beds with a spacing of $50 \mathrm{~cm}$ between beds. The treatments comprised of five drip irrigation levels at 50, 65, 80, 95 and $100 \%$ with four replications. Each plant was fertigated once in three days through a drip emitter with nutrient concentration levels of N:P:K- 175:125:300 kg ha-1 from planting to the end of the crop.

Plants were pruned to a single stem by removing lateral shoots. Fruits set on nodes of the main stem and lateral shoot. Harvesting was started 55 days after sowing. As practiced by commercial growers, curved or deformed fruits were removed from the plant during pruning operations and marketable immature fruits were harvested in 2-3 days and then weighed. The number of fruits were also counted.

Statistical analysis of the data was performed using a completely randomized design with four replications. The analysis of variance was also accounted for factors. The level of the significant difference (LSD at $\mathrm{P}<0.05)$ was used in the ANOVA to test the effect of irrigation treatments on different response variables (Steel and Torrie, 1980).

Field water use efficiency of each treatment was computed using the following equation:

\section{WUE $=$ Y/WR}

Where, $\mathrm{Y}=$ Weight of marketable produce of the crop, $\mathrm{kg} \mathrm{ha}^{-1} ; \mathrm{WR}=$ Depth of water used, $\mathrm{cm}$.

The expenditure incurred from field preparation to harvest was worked out and expressed as Rs.ha ${ }^{-1}$. The salad cucumber yield was computed per hectare and the total income was worked out based on the prevailed minimum market rate of Rs. 30/- per kg. The net return was calculated by subtracting the cost of cultivation from gross return. The cost of naturally ventilated polyhouse and drip system for one hectare was worked out based on current market rates. The life of the NVPH was assumed to be 10 years and drip system for 6 years. Prevailing market price of NVPH and drip components obtained from a standard firm was used. Interest on capital investment was taken as 8 per cent per annum.

The benefit cost ratio (BCR) was worked out by using the formula suggested by Palaniappan (1985):

\section{BCR = Gross Return $\left(\right.$ Rs.ha $\left.^{-1}\right) /$ Total cost of cultivation $\left(\right.$ Rs.ha $\left.^{-1}\right)$}

\section{RESULTS AND DISCUSSION}

Crop yield is always an important effective and economic index consideration in the crop development. The number of fruits per plant is an important determinant of yield in salad cucumber. The highest fruit number (49) was found in 65\% drip irrigation level and the lowest (35) in the lowest level of drip irrigation at 50\% (Table 1). Irrigation treatments had significant effects $(\mathrm{P}<0.05)$ on fruit number. However, interaction within groups was found to be non-significant (Table 2). The highest mean fruit weight $\left(7.194 \mathrm{~kg} \mathrm{plant}^{-1}\right)$ was obtained from drip irrigation level of $65 \%$ and the lowest $\left(5.043 \mathrm{~kg} \mathrm{plant}^{-1}\right)$ at $50 \%$ drip irrigation level (Table 1). Irrigation treatments had significant effects $(\mathrm{P}<0.05)$ on fruit weight. However, interaction within groups was found to be non-significant (Table 3). The highest yield $\left(88.8 \mathrm{t} \mathrm{ha}^{-1}\right)$ was obtained with 65\% drip irrigation level and the lowest $\left(62.26 \mathrm{t} \mathrm{ha}^{-1}\right)$ from the treatment with a drip irrigation level of $50 \%$ (Table 1). Irrigation treatments had significant effects $(\mathrm{P}<0.05)$ on fruit yield. However, interaction within groups was found to be non-significant (Table 4).

When a multiple comparison was made using Post Hoc test, yield from 50\% drip irrigation level, which watered the least was comparatively low and showed significant difference. There was no significant difference among other four treatments (Table 1). The graph represents the effect of drip irrigation levels on yield of salad cucumber (Fig. 1).

Table 1. Effect of drip irrigation levels on yield of salad cucumber

\begin{tabular}{lccc}
\hline Treatment & Fruit number $\left(\right.$ plant $\left.^{-1}\right)$ & ${\text { Fruit weight }\left(\mathrm{kg} \mathrm{plant}^{-1}\right)}^{\text {Fruit yield }\left(\mathrm{t} \mathrm{ha}^{-1}\right)}$ \\
\hline T1: 50\% drip irrigation level & $35^{\mathrm{b}}$ & $5.043^{\mathrm{b}}$ & $62.26^{\mathrm{b}}$ \\
T2: 65\% drip irrigation level & $49^{\mathrm{a}}$ & $7.194^{\mathrm{a}}$ & $88.8^{\mathrm{a}}$ \\
T3: 80\% drip irrigation level & $44^{\mathrm{a}}$ & $7.133^{\mathrm{a}}$ & $88.06^{\mathrm{a}}$ \\
T4: 95\% drip irrigation level & $45^{\mathrm{a}}$ & $6.705^{\mathrm{a}}$ & $82.77^{\mathrm{a}}$ \\
T5: $100 \%$ drip irrigation level & $44^{\mathrm{a}}$ & $6.625^{\mathrm{a}}$ & $81.79^{\mathrm{a}}$ \\
\hline
\end{tabular}

* Mean value of observations from 20 plants in 4 replications.

*Figures given in parenthesis are SE; means of fruit weight, fruit number and fruit yield in each column with superscripts of same letters do not differ significantly.

*The mean difference is significant at the 0.05 level. 
Effect of Drip Irrigation Levels on Yield of Salad Cucumber under Naturally Ventilated Polyhouse

Table 2. ANOVA of data on fruit number of salad cucumber in various irrigation treatments

\begin{tabular}{lcccccc}
\hline Source & Sum of Squares & df & Mean Square & F & Sig. & Remarks \\
\hline Block & 140.550 & 3 & 46.850 & 2.524 & 0.107 & NS \\
Treatment & 401.700 & 4 & 100.425 & 5.411 & 0.010 & $*$ \\
Error & 222.700 & 12 & 18.558 & & & \\
Total & 764.950 & 19 & & & & \\
\hline
\end{tabular}

* - significant at $5 \%$ level, NS- not significant

Table 3. ANOVA of data on fruit weight of salad cucumber in various irrigation treatments

\begin{tabular}{lcccccc}
\hline Source & Sum of Squares & df & Mean Square & F & Sig. & Remarks \\
\hline Block & 3.276 & 3 & 1.092 & 1.539 & 0.255 & 0.022 \\
Treatment & 12.218 & 4 & 3.054 & 4.305 & & $*$ \\
Error & 8.515 & 12 & 0.710 & & \\
Total & 24.008 & 19 & & & \\
\hline
\end{tabular}

* - significant at $5 \%$ level, NS- not significant

Table 4. ANOVA of data on fruit yield of salad cucumber in various irrigation treatments

\begin{tabular}{lcccccc}
\hline Source & Sum of Squares & df & Mean Square & F & Sig. & Remarks \\
\hline Block & 499.363 & 3 & 166.454 & 1.539 & 0.255 & NS \\
Treatment & 1861.977 & 4 & 465.494 & 4.304 & 0.022 & $*$ \\
Error & 1297.810 & 12 & 108.151 & & & \\
Total & 3659.15 & 19 & & & & \\
\hline
\end{tabular}

* - significant at $5 \%$ level, NS- not significant

Among the drip irrigation levels, the highest field water use efficiency $\left(6148.31 \mathrm{~kg} \mathrm{ha}^{-1} \mathrm{~cm}^{-1}\right)$ was found at $65 \%$ irrigation level, indicating comparatively more efficient use of irrigation water (Table 5) with a possibility of water saving of 35\% water by adopting T2 (1.3 litre plant ${ }^{-1}$ day $\left.^{-1}\right)$ over control T5 (2 litre plant ${ }^{-1}$ day $\left.^{-1}\right)$. The graph represents the effect of drip irrigation levels on water use efficiency of salad cucumber (Fig. 2).

Table 5. Field water use efficiency of salad cucumber as influenced by drip irrigation levels

\begin{tabular}{lcccc}
\hline \multicolumn{1}{c}{ Treatment } & $\begin{array}{c}\text { Yield } \\
\left(\mathrm{kg} \mathrm{ha}^{-1}\right)\end{array}$ & $\begin{array}{c}\text { Water used } \\
(\mathrm{cm})\end{array}$ & $\begin{array}{c}\text { Water saving } \\
(\%)\end{array}$ & $\begin{array}{c}\text { Water use efficiency } \\
\left(\mathrm{kg} \mathrm{ha}^{-1} \mathrm{~cm}^{-1}\right)\end{array}$ \\
\hline T1: 50\% drip irrigation level & 62256 & 11.11 & 50 & 5603.35 \\
T2: 65\% drip irrigation level & 88804 & 14.44 & 35 & 6148.31 \\
T3: 80\% drip irrigation level & 88060 & 17.78 & 20 & 4953.65 \\
T4: 95\% drip irrigation level & 82770 & 21.11 & 5 & 3920.90 \\
T5: 100\% drip irrigation level & 81786 & 22.22 & 0 & 3680.57 \\
\hline
\end{tabular}

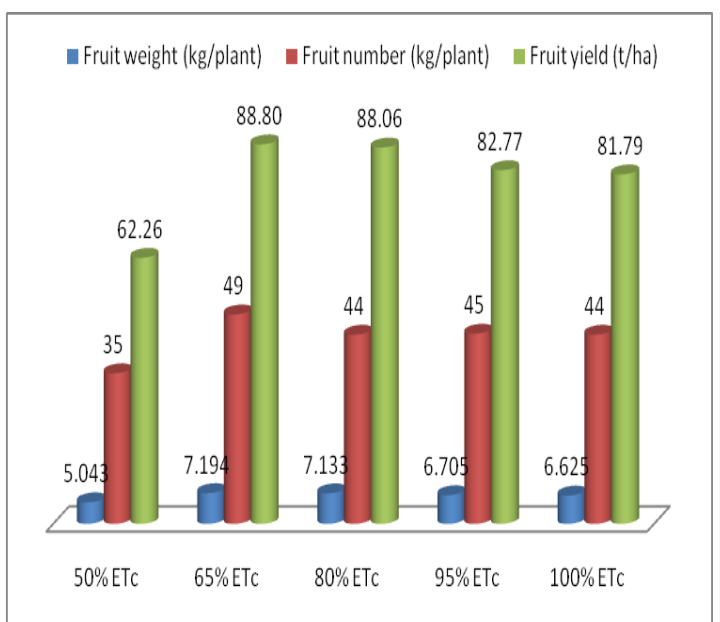

Fig. 1. Effect of drip irrigation levels on yield

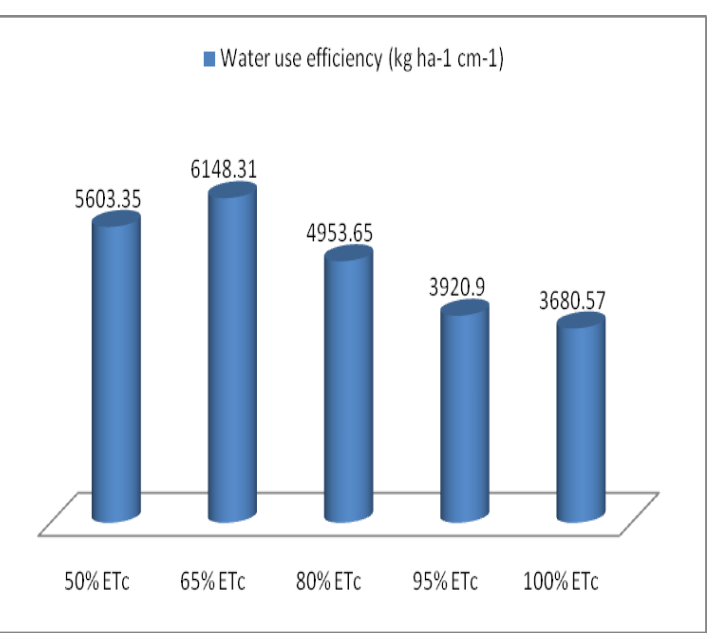

Fig. 2. Effect of drip irrigation levels on WUE 
The maximum net return of Rs. $18,83,327$ per ha could be obtained by using drip irrigation level of $65 \%$ with a Benefit Cost (BC) ratio of 3.41 (Table 6).

Table 6. Economics of salad cucumber as influenced by drip irrigation levels

\begin{tabular}{lccccc}
\hline \multicolumn{1}{c}{ Treatment } & $\begin{array}{c}\text { Crop yield } \\
\left(\mathrm{t} \mathrm{ha}^{-1}\right)\end{array}$ & $\begin{array}{c}\text { Gross return } \\
\left({\mathrm{RS} . \mathrm{ha}^{-1)}}\right.\end{array}$ & $\begin{array}{c}\text { Total cost* } \\
\left(\mathrm{Rs.ha}^{-1}\right)\end{array}$ & $\begin{array}{c}\text { Net return } \\
\left(\mathrm{Rs.ha}^{-1}\right)\end{array}$ & $\begin{array}{c}\text { Benefit Cost } \\
\text { ratio }\end{array}$ \\
\hline T1: 50\% drip irrigation level & 62.256 & 1867680 & 780793 & 1086887 & 2.39 \\
T2: 65\% drip irrigation level & 88.804 & 2664120 & 780793 & 1883327 & 3.41 \\
T3: 80\% drip irrigation level & 88.060 & 2641800 & 780793 & 1861007 & 3.38 \\
T4: 95\% drip irrigation level & 82.770 & 2483100 & 780793 & 1702307 & 3.18 \\
T5: 100\% drip irrigation level & 81.786 & 2453580 & 780793 & 1672787 & 3.14 \\
\hline
\end{tabular}

*Includes the costs of drip irrigation system, NVPH construction and cost of cultivation

\section{CONCLUSION}

Indian agriculture today faces the challenge of meeting demand for safe and quality food. Care has to be taken in protecting the natural resources and the environment in the race for food security. Water is a major input in agriculture. The water use efficiency of the crops has to be increased in order to reduce the water loss from the field. Drip irrigation system is considered as the most effective micro irrigation method, as water is applied directly into soil at the crop root zone.

The results of the study showed that drip irrigation levels have significant $(\mathrm{P}<0.05)$ effects on crop yield. There were significant positive correlations $(\mathrm{P}<0.01)$ between fruit number, fruit weight and fruit yield. Increase in fruit number was the most important factor representing yield increase. Fruit yield was almost uniform except in T1: 50\% drip irrigation level (1 litre plant ${ }^{-1}$ day $^{-1}$ ), which watered the least. The yield obtained from T2 was statistically similar to T5 (control). Thus T2: 65\% drip irrigation level (1.3 litre plant ${ }^{-1}$ day $\left.^{-1}\right)$ was the most effective treatment with $35 \%$ water saving with highest water use efficiency $\left(6148.31 \mathrm{~kg} \mathrm{ha}^{-1} \mathrm{~cm}^{-1}\right)$, yield (88.8 $\mathrm{t} \mathrm{ha}^{-1}$ ) and Benefit Cost ratio (3.41) compared to the control T5: 100\% drip irrigation level (2 litre plant $^{-1}$ day $\left.^{-1}\right)$. Hence it can be concluded that drip irrigation level of $65 \%$ (1.3 litre plant ${ }^{-1}$ day $\left.^{-1}\right)$ is the best irrigation level recommendation for salad cucumber grown under naturally ventilated polyhouse in order to get higher economical cucumber yield.

\section{ACKNOWLEDGEMENTS}

The financial support and encouragement from the National Committee on Plasticulture Applications in Horticulture (NCPAH), Ministry of Agriculture, Govt. of India, New Delhi is gratefully acknowledged. The authors are thankful to the Dean, Kelappaji College of Agricultural Engineering and Technology, Tavanur for providing necessary facilities and support. Authors also thank Dr. Berin Pathrose, Assistant Professor, Krishi Vigyan Kendra, Malappuram for his constant support for adopting proper plant protection measures in the study.

\section{REFERENCES}

[1] V.S. Dunage, P. Balakrishnan and M.G. Patil. Water use efficiency and economics of tomato using drip irrigation under net house conditions. Karnataka J. Agric. Sci. 22(1), 2009, 133-136.

[2] F.S. Nakayama and D.A. Bucks. Trickle irrigation for crop production, design, operation and management. Elsevier Scientific Publishers, Netherlands. 1986.

[3] Maqsood Ahmed, Abdul Hamid and Zarqa Akbar. Growth and yield performance of six cucumber (Cucumis sativus L.) cultivars under agro-climatic conditions of Rawalakot, Azad Jammu and Kashmir. International Journal of Agriculture \& Biology, 6 (2), 2004, 396-399.

[4] Wang Xinyuan, Li Dengshun and Zhang Xiying. Relationship between irrigation amount and yield of cucumber in solar greenhouse. J. China Vegetables. 1999-01.

[5] Pei Xiaobo, Zhang Fuman and Gao Lihong. Study on water requirement of cucumber of different cropping in solar greenhouse. J. Chinese Agricultural Science Bulletin. 2002-04.

[6] LI Shao, XUE Xu-zhang, GUO Wen-shan, LI Xia and CHEN Fei. Effects of water supply tension on yield and water use efficiency of greenhouse cucumber. Journal: Scientia Agricultura sinica, 2010-2.

[7] S. P. Palaniappan. Cropping systems in the tropics- Principles and Management. Wiley Eastern Ltd., New Delhi, 1985 - 215. 